\title{
Hydrogeological problems of the Křtinský valley in the Moravian karst
}

\author{
Sandra Kejíková
}

Masaryk University, Faculty of Science; Kotlářská 267/2, 61137 Brno, Czech Republik; e-mail: sandrakejikova@gmail.com

(c) 2015 Authors. This is an open access publication, which can be used, distributed and reproduced in any medium according to the Creative Commons CC-BY 4.0 License requiring that the original work has been properly cited.

The Výpustek cave is located in the middle part of the Moravian Karst, which is the most known, largest and most karsted area in the Czech Republic. Hydrogeology of the area is very interesting, surrounding terrain has greatly changed due to extensive changes in the last 100 years. Some swallow holes were blocked, others newly created as the Krrtinský stream we didn't have map wit active swallow holes.

Already in the mid-20th century, hydrogeology of Krrtinský stream was studied by Czech researchers. We decided after nearly 60 -year break to continue with research of unknown karst water of Krrtinský valley and we performed a new series of measurements.

Total of 8 tracer experiments was previously performed and subsequently published on Křtinský stream. Two tracer tests were performed in research area of the Krrtinský valley.

The first test was carried out between swallow hole A and outflow (Burkhardt \& Zedníček, 1950, 1951-1955), the second test was between swallow hole $\mathrm{E}$ and the outflow of Krrtinský stream (Kůrkova et al. 2010) where I cooperated. Kůrkova et al. (2010) indicates distance between swallow hole E, localized before the Výpustek cave and the outflow of Krrtinský stream as 3870 metres. From these values it was possible to determined that the distance between the first swallow hole A and fifth swallow hole $\mathrm{E}$ is 330 metres, among which are three more swallow holes B, C, D, which are activated only at higher water levels.
The fluorescein was used as good visibly tracer for both realized tests. Both tests confirmed the relatively slow flow. In the first test the transit time after injection of tracer was 339 hours (14 days). Time when injected tracer has passed the second sampling site was 190 hours (8 days). It is necessary to take into consideration that Burkhardt \& Zedníček (1950, 1951-1955) in 1948 performed a hydrographic experiment in which water lost only into the first two swallow holes (A and B). According to the test results in 1948 no active flow which clearly confirmed bifurcation of Křtinský stream was found in the Výpustek cave. It means that the first test, which was injected fluorescein into the swallow hole A was injected into northern branch of the Krrtinský stream.

The second test in 2009 was performed by injecting fluorescein to the swallow hole E implemented in the southern branch. Swallow holes A, B, C, D, E, F of the Krrtinský stream were re-localized and new swallow hole known as "U smrku" was described. We performed an individual flow measurement with method of dilution in the research area of Krrtinský stream. Following the test results, a reduction in absorption capacity of the main swallow hole E in the year 2009 was found. This swallow hole lost $50 \%$ of water with flow rate $16 \mathrm{~L} \cdot \mathrm{s}^{-1}$ since 2009 . The swallow hole "U smrku" has shown an absorption capacity $54 \%$ with flow rate of $8.40 \mathrm{~L} \cdot \mathrm{s}^{-1}$. Hydrogeological problems of the Krrtinský stream and surrounding platforms are very complicated and it would be beneficial to 
continue with the tracer measurements on affluents of the Krrtinský stream.

\section{REFERENCES}

Burkhardt R. \& Zedníček O., 1950. Hydrografické poznámky $\mathrm{k}$ problému Křtinského potoka $\mathrm{v}$ Moravském krasu. Československý kras, 3, 223-236.
Burkhardt R. \& Zedníček O., 1951-1955. Údolí Křtinského potoka v Moravském krasu a jeho jeskyně. Př́loha časopisu Československý kras, 4-7, 1-116.

Kůrková I., Bruthans J., Kejíková S., Šlechta S., Lejska S. \& Dostál I. , 2010. Nové poznatky o charakteru podzemní části toku Křtinského potoka (Moravský kras): stopovací zkoušky, chemizmus a vyhodnocení měřených průtoků. Speleofórum, 29, 128-132. 